\title{
PARTISIPASI PETANI DALAM PERLAKUAN BENIH UNTUK PENINGKATAN KUALITAS BIBIT TANAMAN PADI SAWAH
}

\section{Participation of Farmers in Seeding Treatment for Improvement Quality of Rice Plant Seeds}

\author{
Achdiyat $^{1 *}$, Irvan Varinto ${ }^{2}$ \\ ${ }^{1}$ Program Studi Teknologi Mekanisasi Pertanian \\ ${ }^{2}$ Program Studi Penyuluhan Pertanian Berkelanjutan \\ Jurusan Pertanian Politeknik Pembangunan Pertanian Bogor \\ *Email: iachdiyat@yahoo.co.id
}

\begin{abstract}
Seed treatment is strived to secure and improve the growth and development of lowland rice plants. It is done because lowland rice plants' production does not meet the expectations; the low productivity of lowland rice plants is $61.35 \mathrm{~kW} / \mathrm{ha} / \mathrm{th} / \mathrm{GKP}$. The study aims to describe the level of participation of farmers in seed treatment, analyze factors related to farmers' participation in seed treatment, and develop strategies to increase farmer participation. The study was conducted from April to July 2019 in Tambaksari District, Ciamis Regency, West Java. The target is farmers who are members of the farmer group with the commodity paddy. The total respondents were 71 farmers. Data was collected through semi-structured interviews with closed questionnaires and direct observation. Descriptive analysis is used to describe the level of farmer participation, while correlation analysis is used to find out factors related to farmer participation. Paddy farmers' involvement in seed treatment activities is included in the "medium" category. Factors related to farmers' participation in seed treatment are the government's willingness, ability, and support and the availability of agricultural production facilities. Need to be done: increasing the intensity of extension activities, training in how to give treatment to lowland rice seeds, making seed selection, and measuring soil $\mathrm{pH}$ to achieve the goal of improving the quality of rice field seedlings and more optimal plant development. The procurement of production facilities is needed by farmers in superior seeds, water reservoirs, and growth regulatory substances.
\end{abstract}

Keywords: paddy rice seeds, participation, counseling, seed treatment, strategy

\begin{abstract}
ABSTRAK
Perlakuan benih diupayakan untuk pengamanan dan peningkatan kualitas pertumbuhan dan perkembangan tanaman padi sawah. Hal ini dilakukan karena usahatani tanaman padi sawah belum sesuai dengan harapan, produktifitas tanaman padi sawah masih rendah yaitu 61,35 kW/ha/th/GKP. Kajian ini bertujuan untuk mendeskripsikan tingkat partisipasi petani dalam perlakuan benih, dan analisis faktor-faktor yang berhubungan dengan partisipasi petani dalam perlakuan benih serta menyusun strategi peningkatan partisipasi petani. Kajian dilaksanakan di Kecamatan Tambaksari, Kabupaten Ciamis, Jawa Barat. Sasaran yaitu petani yang tergabung dalam kelompoktani dengan komoditas padi sawah dengan total responden sebanyak 71 petani. Pengumpulan data dilakukan melalui wawancara semi terstruktur dengan kuesioner tertutup dan observasi langsung. Analisis deskriptif digunakan untuk menggambarkan tingkat partisipasi petani, sedangkan analisis korelasi digunakan untuk mengetahui faktor yang berhubungan dengan partisipasi petani. Partisipasi petani padi sawah terhadap kegiatan perlakuan benih termasuk dalam kategori "sedang". Faktor yang berhubungan dengan partisipasi petani dalam perlakuan benih adalah: kemauan, kemampuan, dan dukungan pemerintah, serta ketersediaan sarana produksi pertanian. Perlu dilakukan peningkatan intensitas kegiatan penyuluhan, pelatihan cara memberi perlakuan pada benih padi sawah, cara melakukan seleksi benih, dan pengukuran $\mathrm{pH}$ tanah untuk tercapai tujuan peningkatan kualitas bibit tanaman padi sawah dan perkembangan tanaman lebih optimal. pengadaan sarana produksi yang dibutuhkan petani berupa benih unggul, embung air, dan zat pengatur tumbuh.
\end{abstract}

Kata Kunci: bibit padi sawah, partisipasi, penyuluhan, perlakuan benih, strategi 


\section{PENDAHULUAN}

Kecamatan Tambaksari terletak di wilayah bagian Timur Kabupaten Ciamis, ketinggian tempat $300-600$ meter di atas permukaan laut, merupakan satu dari 36 kecamatan di Kabupaten Ciamis. Luas wilayah Kabupaten Ciamis secara keseluruhan mencapai 143.387 ha, sedangkan Kecamatan Tambaksari memiliki luas wilayah $6.020,13$ ha. Luas wilayah Kecamatan Tambaksari terbagi atas beberapa kawasan berdasarkan kegunaanya diantaranya seperti kawasan pertanian, perkebunan, kehutanan, permukiman, dan kawasan lainnya. Kawasan tersebut dikelola oleh masyarakat berdasarkan kepemilikan lahan dan beberapa kawasan yang dimiliki oleh pemerintah setempat maupun milik negara seperti halnya kawasan hutan yang cenderung dikelola oleh pemerintah. Selain itu, kawasan pertanian dikelola oleh kelompok masyarakat tani yang merupakan pelaku utama dan pelaku usaha dibidang pertanian yang didampingi oleh penyuluh pertanian.

Berdasarkan data Programa Kecamatan Tambaksari, komoditas tanaman jagung yang diusahakan oleh petani saat ini berjalan cukup baik dengan produktifitas per tahun mencapai 70,89 $\mathrm{kW} / \mathrm{ha}$ dengan persentase peningkatan $1,72 \%$ per tahun. Sedangkan produktifitas tanaman padi saat ini baru mencapai 61,35 $\mathrm{kW} / \mathrm{ha} / \mathrm{tahun} / \mathrm{gkp}$ dengan persentase peningkatan $0,20 \%$ per tahun. Keadaan tersebut disebabkan oleh beberapa faktor yang mempengaruhi tingkat produksi tanaman padi antara lain faktor internal maupun ekternal petani. Hal ini seperti kemampuan petani dalam kegiatan budidaya yang kurang tepat, kurangnya perhatian petani dalam penggunaan sarana dan prasarana usahatani misalnya dalam penyiapan bahan tanam, kualitas bibit yang ditanam, penggunaan pupuk, pengendalian hama dan penyakit tanaman, penggunaan teknologi modern dan banyak faktor lainnya yang berpengaruh terhadap keberhasilan usaha tani. Permasalahan yang paling utama adalah penyiapan bahan tanam berupa benih padi sawah. Kegiatan yang perlu dilakukan dalam penyediaan bahan tanam yaitu perlakuan benih sebelum tanam.

Perlakuan benih merupakan kegiatan utama dalam penyediaan bahan tanam berupa bibit tanaman padi sebelum disemai (Mahmud et al, 2010). Kegiatan perlakuan benih menentukan tingkat keberhasilan tanaman dalam beradaptasi, tumbuh dan berkembangnya proses produksi padi. Keberhasilan dalam memberikan perlakuan benih akan mempercepat masa dormansi benih sehingga benih lebih cepat tumbuh dan berkembang. Adapun kegiatan dalam perlakuan benih terdiri dari kegiatan seleksi benih, perendaman, penggunaan fungisida dan zat perangsang tumbuh (ZPT). Penggunaan bahan-bahan tambahan tersebut dimaksudkan untuk meningkatkan daya tahan benih terhadap serangan hama dan penyakit pada tanaman padi sehingga sangat penting untuk dilakukan. Kegiatan tersebut juga tentunya membutuhkan kemampuan dan kesadaran setiap petani dalam melakukan kegiatan perlakuan benih, sehingga tidak jarang petani mengabaikan kegiatan perlakuan benih dalam usahataninya. Keadaan tersebut diduga dipengaruhi oleh rendahnya tingkat partisipasi petani untuk belajar dan mencoba melakukan budidaya tanaman padi dengan baik sesuai dengan prosedur yang dianjurkan.

Tujuan penelitian ini adalah untuk mendeskripsikan tingkat partisipasi petani dalam perlakuan benih untuk peningkatan kualitas bibit tanaman padi sawah, menganalisis faktor-faktor yang berhubungan dengan partisipasi petani dalam perlakuan benih untuk peningkatan kualitas bibit tanaman padi sawah dan merumuskan strategi peningkatan 
partisipasi petani dalam penerapan perlakuan benih untuk peningkatan kualitas bibit tanaman padi sawah.

\section{METODE}

Penelitian ini dilaksanakan di Kecamatan Tambaksari, Kabupaten Ciamis Provinsi, Jawa Barat. Populasi dalam pengkajian ini adalah anggota atau pengurus kelompok tani yang aktif dan berusahatani padi sawah yang berada di tiga desa di Kecamatan Tambaksari yaitu Desa Tambaksari sebanyak 21 responden, Desa Kadupandak sebanyak 19 responden, dan Desa Karangpaningal sebanyak 31 responden, sehingga jumlah total sebanyak 71 responden. Dari setiap desa yang berbeda, diambil dua kelompok tani. Pemilihan desa didasarkan pada potensi komoditas tanaman padi sawah yang paling besar di antara desa yang ada dengan penerapan purposive sampling.

\section{Data dan Pengumpulan Data}

Data yang digunakan terdiri dari data primer dan data sekunder. Data primer merupakan data yang diperoleh langsung dari sumbernya yaitu petani dan penyuluh setempat, yang dikumpulkan menggunakan alat ukur/instrumen berupa daftar pertanyaan (kuesioner) melalui wawancara semi terstruktur (Suyatno dan Sutinah, 2011). Sedangkan data sekunder adalah data yang relevan dengan penelitian yang bersumber dari instansi terkait diantaranya Dinas Pertanian Kabupaten Ciamis, BPP Kecamatan Tambaksari, kantor Kecamatan Tambaksari, kantor desa dan lembaga terkait lainnya. Instrumen yang digunakan dalam pengkajian ini berupa kuesioner tertutup yang telah disediakan pilihan menggunakan skala likert dengan pilihan jawaban 1 sampai 4 . Kemudian untuk pengujian reliabilitas dan validitas instrumen dilakukan dengan cara memberikan kuesioner kepada responden atau petani. Data hasil pengisian kuesioner tersebut kemudian diolah dengan menggunakan program Statistical Package for the Social Sciences (SPSS) 20 (Sujarweni, 2015; Sugiyono, 2014). Hasil pengujian validitas hasilnya diperoleh 42 pertanyan yang valid.

Kriteria penarikan kesimpulan dari hasil pengujian dapat dilihat dari nilai Cronbach's Alpha $(\alpha)$ keseluruhan instrumen menggunakan SPSS versi 20 . Instrumen memiliki tingkat reliabilitas tinggi jika nilai $\alpha>0,60$ (Ratnaningsih, 2010; Walpole, 1993). Hasil uji reabilitas yang telah dilakukan menunjukan bahwa nilai Cronbach's Alpha $(\alpha)$ adalah 0,975 sehingga dapat dikatakan reliabel.

Analisis data yang digunakan dalam pengkajian ini adalah analisis statistik deskriptif dan analisis korelasi dengan bantuan program Statistical Product and Service Solutions (SPSS) versi 20 adalah untuk mendeskripsikan tingkat partisipasi petani dalam perlakuan benih (Sujarweni, 2015). Sementara untuk mengetahui faktor yang berhubungan dengan partisipasi petani dalam perlakuan benih, dilakukan analisis korelasi Rank Spearman. Penghitungan koefisien korelasi dengan rumus sebagai berikut:

$$
r s=\frac{6 \sum d^{2}}{n\left(n^{2}-1\right)}
$$

Keterangan :

rs = koefisien korelasi RankSpearman

$\sum \mathrm{d}^{2}=$ total kuadrat selisih antar ranking

$\mathrm{n} \quad=$ jumlah sampel

Uji Korelasi Rank Spearman bertujuan untuk mengetahui kinerja indikator terlemah berdasarkan jawaban responden menggunakan analisis Non Parametric Kendall's sebagai dasar penentuan rencana tindak lanjut. Hal ini menjadi dasar merumuskan dan merancang materi penyuluhan. Data tersebut dianalisis menggunakan aplikasi SPSS 20. 


\section{HASIL DAN PEMBAHASAN}

\section{Karakteristik Petani}

Dalam pengkajian ini, digunakan beberapa indikator untuk mengidentifikasi karaketristik petani. Indikator tersebut antara lain umur, tingkat pendidikan formal dan lama usaha tani (Widyawati et al.,
2013; Yahya, 2011; Anwarudin, 2017). Hasil tersebut dianalisis secara deskriptif dalam bentuk presentase. Hal ini menunjukan kriteria atau kondisi sosial dan ekonomi responden. Secara rinci hasil analisis karakteristik responden berdasarkan umur, tingkat pendidikan dan lama usaha tani ditunjukkan pada Tabel 1.

Tabel 1 Karakteristik Responden

\begin{tabular}{|c|c|c|c|}
\hline No. & Indikator & Jumlah (orang) & Presentase (\%) \\
\hline \multirow[t]{5}{*}{1.} & Umur (tahun) & & \\
\hline & $<35$ & 3 & 4,23 \\
\hline & $35-45$ & 13 & 18,31 \\
\hline & $46-55$ & 25 & 35,21 \\
\hline & $>55$ & 30 & 42,25 \\
\hline \multirow[t]{5}{*}{2.} & Tingkat Pendidikan & & \\
\hline & PT & 0 & 0 \\
\hline & SMA & 7 & 10 \\
\hline & SMP & 24 & 34 \\
\hline & SD & 40 & 56 \\
\hline \multirow[t]{5}{*}{3.} & Lama Usahatani (tahun) & & \\
\hline & $>15$ & 56 & 79 \\
\hline & $11-15$ & 8 & 11 \\
\hline & $6-10$ & 4 & 6 \\
\hline & $<5$ & 3 & 4 \\
\hline
\end{tabular}

Sumber: Data primer yang diolah (2021)

Berdasarkan Tabel 1 menunjukkan bahwa umur responden sebanyak $42,25 \%$ adalah berumur > 55 tahun. Tingkat pendidikan sebanyak 56\% termasuk pendidikan SD, dengan lama usaha tani sebagian besar sebanyak $79 \%$ yaitu > 15 tahun. Umur responden $>55$ tahun karena kurangnya regenerasi petani. Tingkat pendidikan rendah karena pendidikan bukan prioritas bagi petani. Responden lebih memilih bekerja. Lama usaha tani yang dilakukan sebagian besar > 15 tahun.

\section{Analisis Tingkat Partisipasi Petani}

Menurut Adi (2007), keikutsertaan petani meliputi identifikasi masalah, pemilihan atau perencanaan alternatif solusi untuk menangani masalah. Selain itu, Mardikanto (2009), menyatakan bahwa partisipasi masyarakat merupakan bentuk keterlibatan dan keikutsertaan secara aktif dan sukarela pada kegiatan penyuluhan pertanian. Hasil pengukuran tingkat partisipasi petani ditunjukkan pada Tabel 2.

Tabel 2 Partisipasi Petani Padi Sawah Pada Kegiatan Perlakuan Benih

\begin{tabular}{lcccc}
\hline \multirow{2}{*}{ Kategori } & Nilai & \multicolumn{4}{c}{ Tingkat Partisipasi Petani } \\
& $\geq 36$ & 18 & 25,35 & Nilai Rata-rata Responden \\
\hline Tinggi & $\geq 35,35$ & 32 & 45,07 & 30,83 \\
Sedang & $24-31$ & 29,57 & (Sedang) \\
Rendah & $\leq 23$ & 21 & 100 & \\
\hline Jumlah & & 71 & & \\
\hline
\end{tabular}

Sumber: Data primer yang diolah (2021) 
Berdasarkan Tabel 2 tingkat partisipasi petani dalam perlakuan benih termasuk pada kategori sedang. Hal ini diakibatkan karena sebagian besar petani telah menerapkan kegiatan perlakuan benih namun belum secara konsisten dan belum mengkombinasikan perlakuan benih dengan zat pengatur tumbuh. Hal ini karena banyaknya benih-benih kemasan yang berasal dari bantuan pemerintah maupun benih yang dijual di toko petanian. Benih bantuan pemerintah sangat membantu petani untuk keberlangsungan usaha taninya namun petani kurang tepat dalam memanfaatkannya. Hal ini karena petani berasumsi bahwa benih tersebut merupakan benih yang siap pakai sehingga tidak perlu adanya perlakuan benih. Padahal, pada dasarnya benih kemasan belum tentu terbebas dari organisme pengganggu tanaman baik hama maupun penyakit. Ditambah lagi, benih yang di beli dari produk toko pertanian masih perlu kembali mengecek label yang tertera pada kemasan.

Petani belum memahami pentingnya perlakukan benih sebelum mulai tanam. Petani menganggap bahwa perlakuan benih tidak berdampak signifikan terhadap pertumbuhan OPT. Hal ini merupakan permasalahan yang harus diatasi dengan cara penyuluhan

\section{Analisis Faktor-Faktor yang Berhubungan Signifikan dengan Partsipasi Petani}

Uji Korelasi Spearman Rank bertujuan untuk mengetahui hubungan karakteristik petani, faktor internal, dan faktor eksternal. Pada penelitian ini terdapat beberapa hipotesis untuk menguji pengaruh variabel bebas pada variabel terikat. Hipotesis penelitian antara lain: 1) variabel dependen ( $y$ ) yaitu partisipasi dengan variabel independen yaitu umur $\left(\mathrm{x}_{11}\right)$, tingkat pendidikan $\left(\mathrm{x}_{12}\right)$, dan lama usaha tani $\left.\left(\mathrm{x}_{13}\right) ; 2\right)$ variabel dependen yaitu partisipasi (y) dengan variabel independen yaitu kesempatan $\left(\mathrm{x}_{21}\right)$, kemauan $\left(\mathrm{x}_{22}\right)$, kemampuan $\left(\mathrm{x}_{23}\right)$; dan 3 ) variabel dependen yaitu partisipasi (y) dengan variabel independen yaitu peran penyuluh $\left(x_{31}\right)$, dukungan pemerintah $\left(\mathrm{x}_{32}\right)$, dan ketersedian saprotan $\left(\mathrm{x}_{33}\right)$.

Pengujian hipotesis tersebut menggunakan analisis Spearman Rank. Metode ini bisa menguji pengaruh asosiatif pada variabel penelitian yang memiliki nilai ordinal. Hasil pengujian digunakan untuk menentukan faktor yang paling signifikan pada peningkatan partisipasi petani. Hasil analisis uji korelasi Spearman rank pada penelitian ini ditunjukkan pada Tabel 3.

Tabel 3 Hasil Uji Korelasi Spearman Rank

\begin{tabular}{lllll}
\hline Variabel Dependen & \multicolumn{1}{c}{ Variabel Independen } & $\begin{array}{c}\text { Koef. } \\
\text { Korelasi }(r)\end{array}$ & Signifikan & Keterangan \\
\hline Partisipasi petani $(\mathrm{Y})$ & Umur $\left(\mathrm{X}_{11}\right)$ & 0,006 & 0,959 & Tidak Signifikan \\
& Tingkat pendidikan $\left(\mathrm{X}_{12}\right)$ & $-0,039$ & 0,745 & Tidak Signifikan \\
& Lama usaha tani $\left(\mathrm{X}_{13}\right)$ & $-0,023$ & 0,852 & Tidak Signifikan \\
& Kesempatan $\left(\mathrm{X}_{2.1}\right)$ & 0,146 & 0,224 & Tidak Signifikan \\
& Kemauan $\left(\mathrm{X}_{2.2}\right)$ & 0,468 & $0,000^{* *}$ & Signifikan \\
& Kemampuan $\left(\mathrm{X}_{2.3)}\right.$ & 0,420 & $0,000^{* *}$ & Signifikan \\
& Peran penyuluh $\left(\mathrm{X}_{3.1}\right)$ & 0,190 & 0,113 & Tidak Signifikan \\
& Dukungan pemerintah $\left(\mathrm{X}_{3.2}\right)$ & 0,452 & $0,000^{* *}$ & Signifikan \\
& Ketersediaan saprodi $\left(\mathrm{X}_{3.3}\right)$ & 0,337 & $0,004^{* *}$ & Signifikan \\
\hline
\end{tabular}

Sumber: Data primer yang diolah (2021) 
Berdasarkan Tabel 3, diketahui bahwa hasil analisis korelasi Spearman Rank di peroleh nilai koefisien korelasi kemauan dengan tingkat partisipasi petani sebesar 0,468. Hal ini berarti tingkat hubungan kemauan dengan partisipasi petani cukup kuat dan searah dengan nilai signifikan $0,000^{* *}$. Kondisi ini menunjukkan adanya hubungan yang signifikan antara kemauan terhadap tingkat partisipasi petani. Selain itu, dapat dimaknai bahwa apabila kemauan petani untuk menerapkan kegiatan perlakuan benih meningkat maka tingkat partisipasi petani cenderung akan meningkat terhadap kegiatan perlakuan benih padi sawah yang bertujuan untuk meningkatkan kualitas.

Berdasarkan hasil analisis data dan observasi dilapangan mayoritas petani yang ada di Kecamatan Tambaksari bekerja di sektor pertanian khususnya padi sawah. Sebagian besar petani sudah menerapkan perlakuan benih namun masih dalam kebiasaan yang lama dan yaitu untuk mengecambahkan benih sebelum semai. Selain itu, petani belum mengkombinasikan perlakuan benih dengan zat pengatur tumbuh.

Hasil analisis korelasi Spearman Rank menunjukkan nilai koefisien korelasi kemampuan petani dengan partisipasi petani sebesar $0,420^{* *}$ yang artinya ada hubungan yang signifikan dengan nilai signifikan sebesar $0,000^{* *}$. Dapat disimpulkan bahwa jika kemampuan petani dalam kegiatan perlakuan benih untuk peningkatan kualitas bibit tnaman padi sawah meningkat maka tingkat partisipasi petani cenderung juga akan meningkat. Hasil pengamatan dan wawancara menunjukkan petani mampu menerapkan perlakuan benih. Namun petani belum mengetahui cara peningkatan kualitas bibit tanaman padi menggunakan ZPT. Selain itu, petani belum mampu membuat ZPT menggunakan bahan alami. Padahal ini bisa menyebabkan biaya operasional menjadi lebih murah.
Selanjutnya hasil analisis korelasi Rank Spearman di atas diperoleh nilai koefisien korelasi dukungan pemerintah dengan tingkat partisipasi petani sebesar 0,452 yang artinya hubungan dukungan pemerintah dengan tingkat partisipasi petani cukup kuat dan searah (positif) dengan nilai signifikan sebesar $0,00^{* *}$. Selain itu ada hubungan yang signifikan terhadap tingkat partisipasi petani. Hal ini dapat dimaknai bahwa semakin banyak pemerintah memberi dukungan kepada para petani dalam kegiatan usaha tani khsusnya terhadap penerapan kegiatan perlakuan benih padi sawah maka tingkat partisipasi petani cenderung akan meningkat. Keadaan tersebut dibuktikan dengan adanya bantuan saprodi yang sering diberikan kepada petani seperti benih padi, subsidi pupuk, kapur pertanian, dan alsintan serta adanya programprogram pengembangan dan Asuransi Kegiatan Usahatani Padi (AUTP) serta masih banyak dukungan pemerintah dalam moril seperti keterlibatan dalam memfasilitasi kegiatan Hari Krida Pertanian (HKP) dan upaya-upaya khusus untuk meningkatkan perekonomian petani melalui optimasi kegiatan usahatani.

Kemudian hasil analisis korelasi Spearman Rank di atas di peroleh nilai koefisien korelasi ketersediaan saprotan sebesar 0,337 yang artinya hubungan ketersediaan saprotan dengan tingkat partisipasi petani cukup kuat dan searah (positif) serta hubungannya sangat signifikan terhadap tingkat partisipasi petani dengan nilai signifikan sebesar $0,004^{* *}$. Sehingga dapat dimaknai bahwa semakin banyak dan semakin mudah sarana produksi pertanian tersedia di sekitar petani makan tingkat partisipasi petani dalam kegiatan perlakuan benih cenderung akan meningkat.

Berdasarkan hasil wawancara dan observasi langsung dengan beberapa ketua kelompoktani dan petani menyatakan bahwa beberapa 
kelompoktani tidak memiliki alat-alat tersebut dan tidak semua bahan tersedia di kelompok melainkan milik pribadi masingmasing anggota kelompok. sebagian petani memiliki alat dan bahan tersebut namun tidak ataupun belum digunakan untuk kegiatan perlakuan benih selain itu sebagian besar petani tidak memiliki ZPT atau hormon perangsang tumbuh untuk perlakuan benih. Jika dilihat dari ketersediaan saprotan lainnya kendala yang paling sering adalah ketersediaan benih yang tahan terhadap penyakit endemik yaitu penyakit Blas (Pyricularia oryzae). Hal ini menyebabnya penggunaan biaya yang cukup mahal untuk mendapatkan benih yang tahan penyakit blas dan ketersediaan benih ini terbatas jumlahnya sehingga petani terlambat dalam melakukan budidaya padi sawah. Hal ini menjadi faktor penyebab jadwal penanaman padi menjadi tidak serempak.

\section{Kaji Terap}

Ditetapkan satu desa untuk lokasi petak percontohan dengan penerapan perlakuan benih yaitu Desa Tambaksari kelompok tani Mekarsari dengan luasan $420 \mathrm{~m}^{2}$. Varietas benih padi sawah yang digunakan adalah varietas Mapan P-05, dengan sistem tanam jajar legowo $2: 1$. Adapun kegiatan pengamatan yang dilakukan yaitu warna daun, tinggi tanaman, jumlah anakan serta tujuan kegiatan kaji terap/petak percontohan ini, untuk menunjukkan kepada responden mengenai budidaya padi sawah dengan penerapan perlakuan benih.

\section{Pengamatan Warna Daun}

Berdasarkan hasil analisis pengamatan tanaman dengan perlakuan benih serya menggunakan Zat Pengatur Tumbuh (P1) dengan perbandingan tanpa perlakuan Zat Pengatur Tumbuh (P2) tidak berpengaruh terhadap warna daun tanaman padi sawah. Dengan tujuan pengamatan ini berdasarkan hasil secara objektif dalam pengamatan warna daun tanaman pada padi sawah terdapat dua perlakuan. Adapun hasil pengamatan warna daun tanaman padi sawah hasl perlakuan pada penelitian ini dapat dilihat pada Tabel 4.

Tabel 4 Hasil Rata-Rata Pengamatan Warna Daun Tanaman Padi Sawah

\begin{tabular}{ccccccc}
\hline \multirow{2}{*}{ Perlakuan } & $\mathbf{7}$ Umur Tanaman (MST) \\
\cline { 2 - 7 } & $\mathbf{3}$ & $\mathbf{4}$ & $\mathbf{5}$ & $\mathbf{6}$ & $\mathbf{7}$ & $\mathbf{8}$ \\
\hline P 1 & 3 & 3 & 3,5 & 3,5 & 4 & 4 \\
P 2 & 3 & 3 & 3,5 & 3,5 & 4 & 4 \\
\hline
\end{tabular}

Sumber : Data primer yang diolah (2021)

\section{Pengamatan Tinggi Tanaman}

Berdasarkan hasil analisis pengamatan tanaman padi sawah pada kajian terap, dibuatkan grafik pada gambar agar kegiatan budidaya tanaman padi sawah dengan perlakuan benih dengan menggunakan Zat Pengatur Tumbuh (P1) berpengaruh terhadap pertumbuhan tinggi pada tanaman padi sawah, hasil yang ditunjukan meningkat sesuai dengan titik pada hasil pada hal ini dapat dibuktikan dengan adanya perbedaan selisih perlakuan dengan yang tidak memiliki perbedaan yang berbeda. Adapun hasil pengamatan tinggi tanaman dari masing-masing perlakuan dapat dilihat pada Gambar 1. pertumbuhan pada akhir pengamatan dengan selisih sebesar $12 \mathrm{~cm}$ dengan perbandingan tanaman tanpa perlakuan benih dengan aplikasi Zat Pengatur Tumbuh (P2). Grafik hasil pengamatan pengaruh perlakuan terhadap tinggi tanaman padi sawah ditunjukkan pada Gambar 1. 


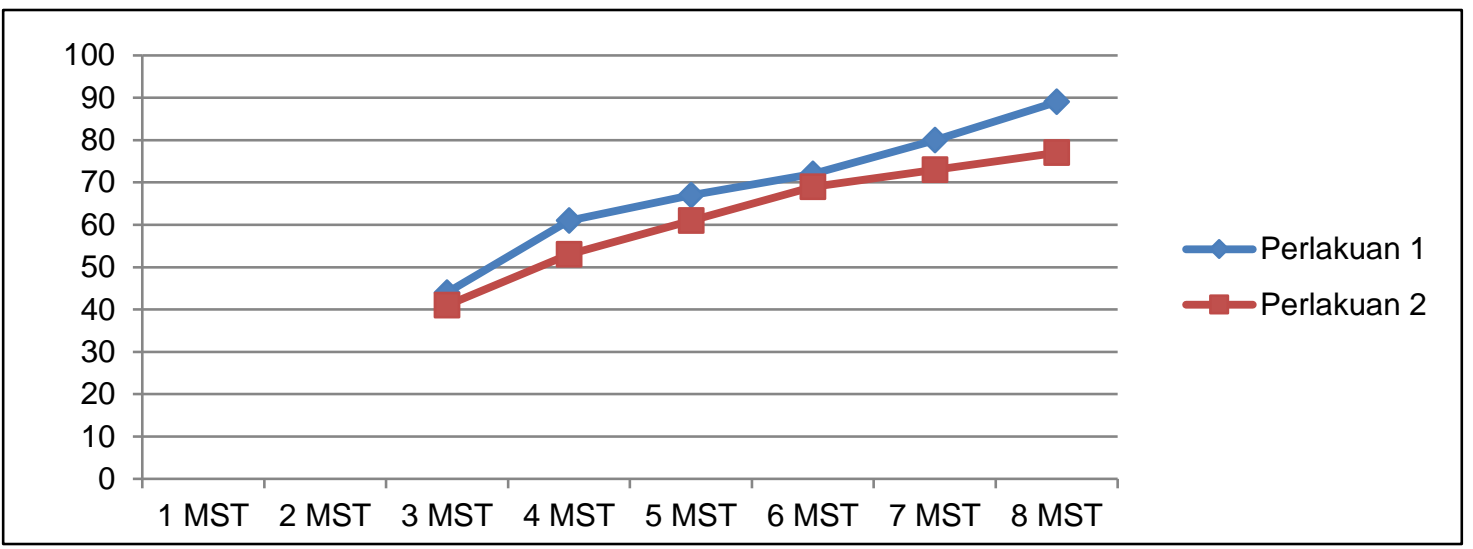

Gambar 1. Grafik hasil pengamatan tinggi tanaman

\section{Pengamatan Jumlah Anakan}

Berdasarkan hasil analisis pengamatan tanaman padi sawah pada kajian terap, kegiatan budidaya tanaman padi sawah dengan perlakuan benih dengan menggunakan Zat Pengatur
Tumbuh (P1) berpengaruh terhadap pertumbuhan jumlah anakan tanaman padi. Hal ini dibuktikan dengan adanya selisih jumlah anakan setiap minggunya mulai minggu ke 3-8. Hasil pengamatan jumlah anakan pada Gambar 2.

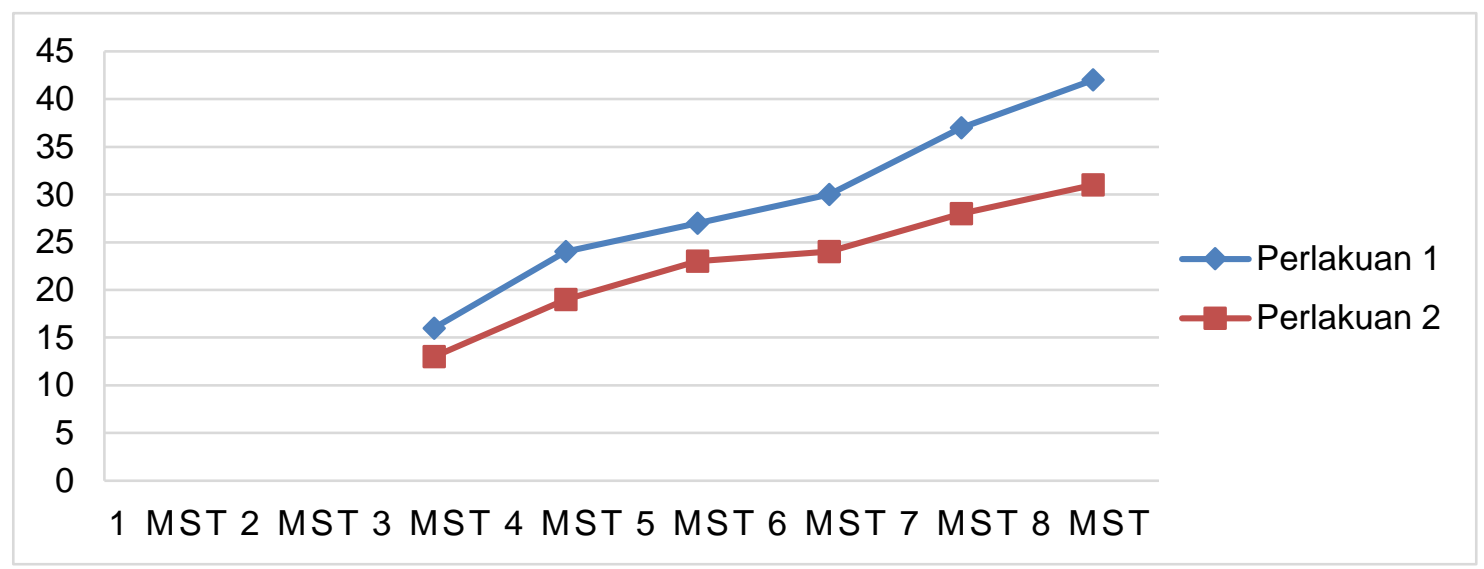

Gambar 2. Hasil pengamatan jumlah anakan

Dengan demikian berdasarkan hasil pengamatan 3 parameter yang di amati dapat disimpulkan bahwa kegiatan perlakuan benih dengan menggunakan Zat Pengatur Tumbuh (ZPT) memiliki pengaruh terhadap pertumbuhan tanaman meliputi tinggi tanaman dan jumlah anakan.

\section{SIMPULAN}

1. Partisipasi petani padi sawah terhadap kegiatan perlakuan benih untuk meningkatkan kualitas bibit tanaman padi sawah di Kecamatan Tambaksari
Kabupaten Ciamis tergolong dalam kategori "sedang".

2. Faktor-faktor yang memiliki hubungan signifikan terhadap partisipasi petani dalam pengkajian ini yaitu faktor internal yang terdiri dari kemauan dan kemampuan petani, serta faktor eksternal yang terdiri dari dukungan pemerintah dan etersediaan sarana produksi pertanian.

3. Strategi untuk meningkatkan partisipasi petani dalam perlakuan benih untuk meningkatkan kualitas bibit tanaman padi sawah dilakukan dengan cara 
meningkatkan faktor - faktor yang berhubungan signifikan dengan partisipasi petani dan melakukan penyuluhan, dan bimbingan teknis (bimtek) terkait kegiatan seleksi benih, pembuatan Zat Pengatur Tumbuh (ZPT) dan pentingnya pengukuran $\mathrm{pH}$ tanah dengan membuat petak percontohan sebagai media terapan hasil kegiatan perlakuan benih. Kegiatan penyuluhan yang intensif dan berkelanjutan dapat membuat partisipasi petani stabil. Metode yang digunakan diantaranya yaitu pertemuan kelompok, demonstrasi cara, ceramah, diskusi, dan media berupa video dan penggunaan benda nyata yang lebih inovatif dan menarik.

\section{SARAN}

Saran yang berkaitan dengan hasil kajian yaitu Perlu dilakukan:

1. Peningkatan intensitas kegiatan penyuluhan dan pelatihan mengenai cara memberi perlakuan pada benih padi sawah, agar petani memahami manfaat dan pentingnya kegiatan perlakuan benih dalam meningkatkan kualitas bibit yang digunakan.

2. Pelatihan bagi petani mengenai cara melakukan seleksi benih dan pengukuran $\mathrm{pH}$ tanah, sehingga tujuan peningkatan kualitas bibit tanaman padi sawah dapat tercapai dan pertumbuhan dan perkembangan tanaman optimal.

3. Pengadaan sarana produksi yang dibutuhkan petani berupa benih unggul, pembuatan embung air dan Zat 9Pengatur Tumbuh (ZPT), sehingga petani dapat meningkatkan kualitas dan produktifitas usahataninya secara intensif dan sesuai harapan.

\section{DAFTAR PUSTAKA}

Adi IR. 2007. Perencanaan Partisipatoris Berbasis Aset Komunitas: Dari Pemikiran Menuju Penerapan. Depok: FISIP UI Press.
Anwarudin. 2017. Faktor Penentu Partisipasi Petani Pada Program Upaya Khusus Padi di Kabupaten Manokwari, Papua Barat. Jurnal PenyuluhanPertanian,http://ojs.unand a.ac.id/index.php/itas/article/downloa $\mathrm{d} / 113 / 94$, diakses tanggal 5 Februari 2019.

Mardikanto. 2009. Sistem Penyuluhan Pertanian . LPP UNS dan UNS Press Surakarta.

Mahmud Y, Netti N, dan Sugiarto 2010. Pengaruh Macam Perlakuan Benih Terhadap Pertumbuhan dan Hasil Bebebrapa Varietas Unggul Baru Tanaman Padi Sawah. Vol. 9 No. 17, Desember 2010 - Pebruari 2011: 53 - 63 .LPPM Universitas Singaperbangsa Karawang.

Ratnaningsih. 2010. Metodologi Penelitian

[Online] Available at; http: //www.ut.ac.id/html/suplemen/mmpi5

202/indeks.html, diakses pada tanggal 20 Maret 2019.

Sugiyono. 2017. Statistika Untuk Penelitian. Bandung: Alfabeta.

Sujarweni, Wiratna. 2015. SPSS Untuk

Penelitian.Yogyakarta: Pustaka Baru Press.

Suyatno, dan Sutinah. 2011. Metode Penelitian Sosial. Jakarta; Kencana.

Walpole RE. 1993. Pengantar Statistika Edisi Ke-3. Jakarta: PT Gramedia Pustaka Utama.

Widyawati dan Pujiyono. 2013. Pengaruh Umur, Jumlah Tanggungan Keluarga, Luas Lahan, Pendidikan, Jarak Tempat Tinggal Pekerja ke Tempat Kerja, dan Keuntungan Terhadap Curahan Waktu Kerja Wanita Tani Sektor Pertanian di Desa Tajuk Kec. Getasan Kab. Semarang. Diponegoro Journal of Economics; https:// media. neliti. com/ media publications/19577-ID-pengaruhumur-jumlah-tanggungan-keluargaluas-la han-pendidikan-jarak-tempatting.pdf,diakses pada tanggal 20 Maret 2019. 
Yahya M. 2016. Adopsi Petani dalam PTT Padi Sawah di Kecamatan Sunggal Kabupaten Deli Serdang Sumatera Utara. Jurnal Agrica Ekstensia; http://www.polbangtanmedan.ac.id/pd f/Jurnal\%202016/Vol\%2010\%20No\% 202/01\%20Mukhlis\%20Yahya.pdf, diakses tanggal 20 Februari 2019. 